TRIBUTE

\section{Tribute: Evan Weissman}

\author{
Tod D. Rutherford * \\ Syracuse University
}

Special issue:

Food as a Tool for Social Change FALK S Univeresse

$\mathrm{I}_{\mathrm{h}}^{\mathrm{t}}$ $\mathrm{t}$ is very difficult for me to write this tribute to Evan. It is easy to find wonderful things to say about his life and work, but it still does not seem possible or right that someone as young, vital, and exceptional should no longer be with us. I will say that I had the great fortune to know Evan, serving as his Ph.D. supervisor in the Department of Geography and the Environment at Syracuse University from August 2006 until his successful defense of his dissertation "Cultivating the City: Urban Agriculture and the Agrarian Question in Brooklyn, New York" in January 2012. He entered our program having recently completed his MA in sociology at the University of Tennessee, and it was clear early on to me that he was a gifted, dedicated student. However, what really stood out for me was not just Evan's selfevident intellectual and scholarly abilities, but his dedication to community activism, combined with his genuine enthusiasm, generosity, and good-naturedness.

One of my great memories of Evan was visiting him in June 2010 while he was doing his field work in Brooklyn, New York. Evan took me on a tour of his study sites ranging from free-range egg production in Crown Heights to community agriculture locations in Red Hook. As we toured around Evan gave a wonderfully insightful commentary about how these constituted not simply isolated examples of urban agriculture but also served a very racially and economically diverse community. Furthermore, they constituted critical parts of a interdependent local production-consumption network, the highlight of which included the transfer of barley mash from a Red Hook microbrewery as feed to some very happy, if not slightly tipsy, Crown Heights chickens.

* Tod D. Rutherford, Department of Geography and the Environment, The Maxwell School of Citizenship and Public Affairs, Syracuse University; trutherf@maxwell.syr.edu 
It is not surprising, then, that even in a time when good academic positions were scarce, Evan received several tenure-stream job offers after his Ph.D. was completed. I was very happy that Evan got his position in the Department of Nutrition and Food Studies at Syracuse University. However, Evan was never an armchair scholar, but felt very strongly the need of a positive, progressive engagement outside of the academy. Thus he was the co-founder of Syracuse Grows, an organization dedicated to grassroot activism to promote better food security by and for Syracuse residents, and also of FoodPlanCNY, which promotes a more ecologically sustainable and socially equitable regional food system in central New York. As such, he was a happy exception to the essentially 'extractive' model characteristic of so much academic research, which often gives little back to the communities they study. In all senses of the term, Evan was an exemplar of Gramsci's 'organic' intellectual.

Evan's passing, then, is a great and irreplaceable loss to his students, the Nutrition and Food Studies programs, the university, and the wider Syracuse community. It is also especially tragic that he leaves behind a young family. However, I feel most fortunate to have known him for the time that I did. He leaves behind a profoundly positive legacy that will inspire new generations of food scholars, students, and activists. 